\title{
IMPACT OF CROSS-BORDER ACQUISITION ON FINANCIAL PERFORMANCE AND STRATEGIC OUTCOME OF ACQUIRING COMPANIES: CASE EXAMPLES FROM INDIAN PHARMACEUTICAL INDUSTRY
}

\author{
Ishrat Rasool \\ Research Scholar, Department of Health \& Hospital Management \\ Jamia Hamdard, New Delhi, India \\ Dr. P.S Raychaudhuri \\ Assistant Professor, Department of Health \& Hospital Management \\ Jamia Hamdard, New Delhi, India
}

\begin{abstract}
Cross-border and domestic merger and acquisitions are considered as fastest means of growth and survival too. This study provides evidence on the value creation by applying inorganic growth strategies based on a sample of Indian pharmaceutical companies. Relying on the key financial ratios, their pre-merger and post-merger financial performances were compared to find whether merger has affected their performance. Based on these multiple financial ratios it has been noted that there was no improvement found in the profitability after merger. The main motives of the mergers and acquisitions like cost reduction, risk spreading etc were compared to the financial results which indicates that the overall motives more or less were achieved by the companies keeping internal factors of acquiring companies constant.
\end{abstract}

Keywords: Cross-border Merger and Acquisition, Key Financial Ratios, Pharmaceutical Sector, Strategic Outcome.

Cite this Article: Ishrat Rasool and P.S Raychaudhuri, Impact of Cross-Border Acquisition on Financial Performance and Strategic Outcome of Acquiring Companies: Case Examples from Indian Pharmaceutical Industry, Journal of Management, 6 (2), 2019, pp. 91-104. http://www.iaeme.com/JOM/issues.asp?JType=JOM\&VType=6\&IType=2

\section{INTRODUCTION}

Mergers refer to the merging of one company into another or two companies getting merged to form a new corporate entity. A merger is generally understood to be a combination or fusion of 
two companies. Acquisition or takeover denotes a company acquiring controlling stake in another so that the acquirer can have management control over the other firm. Mergers are different from acquisitions. Acquisitions imply that a company unilaterally relinquishes its independence and adapts to another firm's plans, while in mergers, all combining firms relinquish their independence and cooperate, resulting in the common corporation (Kerkel et al. 1967, Short, 1967). Corporates worldwide have been aggressively building new competencies and capabilities, and going in for markets based diversification leading to increasing the number of mergers and acquisitions globally. According to a BCG report July 2007, there have been waves of mergers and acquisitions, each wave had its distinct characteristics and strategic motives. As per this report, at the beginning of 20th century, there was a drive for increase in market share for three decades then, another wave of M\&A started which was a long and very ambitious wave. In this wave, companies connected together, the different elements of values chain (vertical merger) from raw materials, production, and distribution. The most recent wave started in 2004 after the internet usage increased and is driven by consolidation motives.

\subsection{Indian Pharmaceutical Industry}

The Indian Pharmaceutical industry is one of the largest \& most advanced among these developing countries. The pharmaceutical market of India is the 3rd largest in terms of volume $\& 13^{\text {th }}$ largest in terms of value. This sector is expected to grow and expand at CAGR of $12.89 \%$ over 2015-20 to reach USD \$55 billion. The Indian pharmaceutical sector accounts for about $2.4 \%$ of the global pharma industry in value terms and $10 \%$ in volume terms. It is one of the highest exporters as it accounts for global exports in generics. In 2016 India exported worth USD 16.4 billion pharma products and it is expected to reach USD 20 billion by 2020 . Some of the pharma companies have developed into mini giants in the Indian market, most of them are into exports (IBEF Report, 2017). Companies like Cipla, Sun Pharma, Kopran, Dr. Reddy's Laboratories, and Cadila Healthcare have all got US-FDA approval which is a prerequisite for access to the US market. Most companies look for the international tie-ups for development of new products, research, and development and launching pad for foreign entry. Most of the recent changes in the sector has increased the competition in the global markets. With the delicensing of the pharmaceutical industry and complemented by scientific talent and research capabilities and Intellectual Property Protection Regime, Indian pharmaceutical industry is all set to take new challenges in the international market. The Indian pharmaceutical market has played a key role in promoting and sustaining development in the vital field of medicines (Bahunia, 2010). One of the major factors that have increased the confidence of foreign multinationals looking opportunities in India is the adoption of new product patent regime in January 2005. This has changed the dynamics of Indian Pharmaceutical sector in other respects too. The companies have started looking for new chemical entities and other drug delivery system, which encourages the acquiring company to look for such target companies with desired strategic capabilities resulting in merger and acquisitions.

\section{LITERATURE REVIEW}

Merger and acquisition has been a topic of interest in the recent history; numerous literature and papers have been researched on the impact of M\&A on corporate capital consolidation and several theories have been proposed to understand the empirical validation of such impacts. Overall merger and acquisitions are corporate restructuring strategies. Merger and acquisition activity could be largely explained by the factors that motivate a firm to grow and expand; it is considered as faster and efficient way of developing firm's asset base and productive capacity (Vyas \& Narayana, 2015). Merger and acquisition help firms' in expanding their horizons whether it is domestic or cross-border. Deals of the corporate restructuring that happen within 
Impact of Cross-Border Acquisition on Financial Performance and Strategic Outcome of

Acquiring Companies: Case Examples from Indian Pharmaceutical Industry

the boundaries of the country are called as domestic mergers and acquisitions while as deals which cross national boundaries of countries are known as cross-border merger and acquisitions. The different studies conducted for analysis of domestic and cross-border mergers and acquisitions found that firm value (market value of firm) is reduced and exert no impact at all which is leading to underperformance (Moeller, 2004; Andrade, 2001; and Agrawal and Jaffe, 2000). As pharmaceutical companies have limited profits due to restrictions in product pricing, they have to think of other strategies of value creation and expansion. Merger and acquisitions add value to the companies by increasing corporate control in the market (Meena, 2014). The creation of value to any acquirer company depends on the type of deal, factors, and characteristics involved in the deal (Dutta and Jog, 2009). However, recent studies opined that mergers and acquisitions generate value for acquirers (Martynova and Rennebog, 2008). Shree (2017) analysed the impact of merger and acquisition on shareholder value and found that market appears to be confused initially and responds slowly to the news of announcement of M\&As. It seems that a small percentage gain to acquiring firms' shareholders is neutralized by comparatively large percentage loss to the target firms' shareholders, making overall impact on combined firms significantly negative. Comparative evaluation of average cumulative abnormal returns of the acquiring and the target firms reveals that there is no significant difference between the two. Thus, the average CARs of the acquiring firms is equal to the average CARs of the target firms. Sophia \& Jacunda (2014) also conducted a study on value addition to acquirer's in India and suggested that acquisitions are neither value creative to Indian acquirers and those acquirers with prior acquisition experience create more value than single acquirers. They also found that using stock as method of payment is no longer value destructive. The key to success of any merger and acquisition lies in the ability of the acquirer to manage the integration of target company into his organization in all respects from winning minds and hearts of employees, resolving issues quickly and eliminate cultural differences that might arise after the acquisition. As all these factors directly affect the production and efficiency of organization (Meena, 2014). For instance, Bertrand and Bestchinger (2011) argue that there are negative effects associated with acquisitions like integration issues and inability to achieve synergy that was expected. They also suggested, firms that are operating in emerging markets have low leverage value due to low M\&A experience and capabilities, especially when opting for international acquisitions. Bertrand \& Zitouna (2008) have also explored in their study about the effect of horizontal acquisitions on the performance of the target firms and found both domestic and cross-border merger \& acquisitions both have similar consequences. Moreover, they found that cross-border acquisitions have more efficiency gains; it may be due to advanced technology they are getting from abroad. Though profits are not increased, there is an increase in productivity which indicates the redistribution of efficiency gains at the production stage.

Saboo and Gopi (2009) carried a comparison of post-merger performance of firms involved in domestic and cross-border acquisition. The hypothesis tested that type of acquisition does not play an important role in the performance of the firms was rejected, as it was found that significant differences existed in the financial ratios of the firm post-merger depending on whether it acquired a domestic firm or a foreign firm. Financial ratios such as debt-equity ratio, return on capital, profit after tax were considered and concluded that most of the indicators improved in one to two years post-merger in case of domestic firms. However, the same financial ratios were negative for firms acquiring foreign firms. The performance of these firms fell for two years continuously in the post deals. In the context of new patent regime Mishra (2010) studied the R\&D behaviour of Pharmaceutical firms in India to examine the innovative efforts of Indian pharmaceutical companies in the new patent regime. He finds that although R\&D expenditure has increased significantly in the current decade in certain specific firms, the increasing R\&D efforts are not widespread across the firms. More than half of the Indian 
pharmaceutical companies do not spend at all on in-house R\&D. It suggested that, a firm's involvement in M\&A with the motive of acquisition of R\&D or sourcing of technology from foreign companies and changes in financial performance does not have any significant impact on its R\&D efforts.

Similarly, Mishra (2011) identified determinants of inter-industry variations in the incidence and extent of M\&A. He finds that the decisions for M\&A across industries are determined by various structural aspects of the market and other business strategies of the firms. While the possibility of M\&A to take place is higher in the industries which have larger market size or greater selling efforts or firms with efficient scale of operation. The extent of these activities varies across industries directly with market size, rate of growth of sales, firms' selling efforts and technology strategies, but inversely with efficient scale of operation. However, the number of sellers does not have any significant influence either on the event or on the extent of M\&A happening. It implies that they are not aimed at gaining greater market power and, therefore, may not be necessarily detrimental to the consumers' interest. According to the Export-Import Bank of India (EXIM) Report (2007), the Indian pharmaceutical sector is changing by implementing cost-effective manufacturing techniques and its domestic market is also growing significantly.

\section{PROBLEM STATEMENT/ RATIONALE OF STUDY}

After the analysis of the literature review, it is quite evident that mergers and acquisitions have become the easiest way for the companies to grow, expand and achieve complementary efficiencies or synergies quickly in the competitive markets. The merger and acquisitions being corporate strategies are of great importance and assessment of the firms' performance. After the merger, it is very critical and important to know whether the desired results are achieved or not. The theories of finance suggest that there are both positive as well as negative impact of mergers and acquisitions on the firms' performance, but according to the merger and acquisitions theory, the successful merger and acquisition increase profitability due to synergy and could result in the monopoly or increase in the efficiency (Beena 2000). While looking at different sectors of economy, mergers and acquisitions have played an important role in growth of every sector. However, assessment of financial performance in the pre and post cross border merger situation in Indian pharmaceutical sector with respect to the strategy has not been conducted and analysed yet. The aim of this paper is to analyse how the Indian pharmaceutical sector performs financially before and after the merger and acquisition. Strategic reasons for merger and acquisitions are also analysed with respect to the financial outcome and the secondary qualitative and descriptive data obtained from expert advisory reports of different financial and strategic analyst firms in the industry. The research gap found is to be analysed. As merger and acquisition being inorganic growth strategy, we need to analyse how it will impact the pharmaceutical industry in particular and economy trends as a whole. The analysis will provide insights about the strategy followed by the selected sample for merger and acquisitions This paper however can be used as an example by other pharmaceutical companies in very initial starting phase of due diligence where they can compare the strategy with respect to the financial performance. The aim is to know how the companies will perform before and after M\&A with the help of financial ratios and whether they achieved desired strategic outcome with the help of secondary data obtained from the strategic reports explaining these M\&A events.

\section{RESEARCH OBJECTIVES}

The present research has been aimed at review of the overall financial performance of the two example firms going for expansion through merger and acquisitions in the Indian 
Impact of Cross-Border Acquisition on Financial Performance and Strategic Outcome of

Acquiring Companies: Case Examples from Indian Pharmaceutical Industry

pharmaceutical industry. An attempt was made to test if there are significant changes in the financial performance after the mergers and acquisitions, whether desired results are achieved by the merger and acquisitions.

1. To assess the pre and post M\&A financial performance of both companies individually.

2. To assess the profitability and operating efficiency in pre \& post M\&A scenario of both companies individually.

3. To assess the liquidity and solvency of both companies individually.

\subsection{Research Hypothesis}

To manifest the above objectives, following hypothesis were formulated:

1. $\mathrm{H}_{0}$ : There is no significant change in profitability and operating efficiency of both companies post-merger.

$\mathrm{H}_{1}$ : There is significant change in profitability and operating efficiency of both companies post-merger.

2. $\mathrm{H}_{0}$ : There is no significant change in liquidity and solvency of both companies postmerger.

$\mathrm{H}_{1}$ : There is significant change in liquidity and solvency of both companies postmerger.

\subsection{Selection of Sample}

The study has been carried out on the two companies sample as a pilot study. So we have selected a sample of two cross border outbound M\&A due to the time and resource constraint. The sample of the study consists two public pharmaceutical companies of India. As the study conducted is exploratory in nature, researchers decided to select two companies as sample for the study. So, selection was based on the criteria of type acquisition i.e. horizontal but crossborder outbound acquisition and type of transaction is acquisition of assets.

\section{RESEARCH METHODOLOGY}

The study has been undertaken for the period of five years pre-merger and five years postmerger, excluded the year of the merger. We have selected two companies Sun Pharmaceuticals and Bilcare Ltd for this study. Both these companies belong to the Indian pharmaceutical sector and have undergone horizontal merger and acquisition. In the pre-merger, the data consisted only of the acquiring firm and after the merger, the data is that of the merged entity. Using paired t-Test and key financial ratios, the pre-merger and post-merger financial performance has been tested and analysed.

Data on key financial ratios of both these pharmaceutical companies depicting the profitability, operating efficiency and liquidity performance. These selected ratio categories give us a true picture of financial performance of any company. These ratios help us to pinpoint the strengths and weaknesses of companies in financial terms by making comparisons and drawing conclusions from those comparisons. The data of required ratios for up to five years after the merger and acquisitions and five years before merger and acquisition year, was extracted from the database of Bloomberg, version 8 March 2018.

Pre-merger and post-merger performance ratios were estimated for both companies and paired t-test was used to assess if there was any statistically significant change in profitability, operating efficiency and liquidity due to mergers and acquisitions. 


\subsection{Key Financial Ratios}

The key financial ratios that are used for analysing the financial performance of both the companies are selected according to designed objectives and are judgemental. These ratios are briefly explained below:

1. Return on Assets (ROA): This ratio measures how much income is generated form our assets i.e. after tax, profits per dollar invested on assets. This ratio is also called the return on investment.

2. Return on Capital (ROC): It measures the return that an investment generates for capital contributors. It basically indicates how effectively a company is utilising its capital by turning it into profits.

3. Earnings before Depreciation, Interest, Tax and Amortization (EBDITA): It is the measurement of company's operating profitability as a percentage of its total revenue. It calculates how much cash profit was made in a year, i.e., cash inflows in a year are calculated as a percentage of total revenue.

4. Operating Profit Margin: It gives the idea about how much profit (before taxes and interest) a company is earning on each dollar of sales. The higher the ratio, the better the company's profitability.

5. Pre-tax Profit margin: This ratio shows the company earnings before tax as a percentage of its total sales or revenues. The higher the ratio, the more profitable company is.

6. Net Profit Margin: This ratio measures the ratio of net profits to revenues of business which means, how much each dollar is collected as revenue is contributing to the profit of a company.

7. Asset Turnover Ratio: It typically measures the value of company's sales/revenues generated over the relative value of its assets.

8. Receivables Turnover Ratio: It indicates the efficiency of a company in extending its credit and in collecting debts on that credit.

9. Quick Ratio (QR): It measures the extent to which a firm can meet its short term obligations with its most liquid assets and without relying upon the sale of its inventories.

10. Current Ratio (CR): It measures the ability of the company to meet its short term obligations with its assets.

11. Total Debt to Equity (TD/E): It is a financial leverage ratio that compares the shareholders equity with the total liabilities (Debt). It measures the percentage of total funds that are provided by creditors versus by owners.

12. Total Debt to Capital (TD/C): This ratio indicates the balance between the debt and equity in firms' long-term capital structure. It is a measurement of firms' long term financial leverage.

13. Total Debt to Total Assets (TD/TA): It is an indicator of financial leverage which indicates the percentage of total assets that were financed by creditors or we can say by debt. 
Impact of Cross-Border Acquisition on Financial Performance and Strategic Outcome of Acquiring Companies: Case Examples from Indian Pharmaceutical Industry

\subsection{Tools of analysis}

\subsubsection{Ratio Analysis}

Ratio is just comparison between two different things. Ratio analysis is well known and most widely used tool for financial analysis. It is a form of Financial Statement Analysis that is used to obtain a quick indication of a firm's financial performance in several key areas.

\subsubsection{T-Test Analysis}

T-test is a statistical test that is used to compare means of two populations. It is considered to be an appropriate test for judging the significance of sample mean. Moreover, it is used for judging significance of the coefficients of simple and partial correlations.

\subsection{Analysis of the data}

The analysis of data usually involves the testing of hypothesis which are formulated to manifest the objectives of research. Pre-merger and post-merger performance ratios were estimated and the averages were computed for the selected companies, during five years before merger and five years after merger. These selected ratios were compared to check if there was any statistically significant change in financial performance due to mergers. The following are the hypothesis framed and tested using paired t-test at $5 \%$ level of significance. We have rejected the $\mathrm{H}_{0}$ (null hypothesis) where the value the significant $\mathrm{p}$-value is less than 0.05 .

\section{Hypothesis 1}

$\mathrm{H}_{0}$ : There is no significant change in profitability and operating efficiency of both companies post-merger.

$\mathrm{H}_{1}$ : There is significant change in profitability and operating efficiency of both companies post-merger.

\subsubsection{SUN PHARMACEUTICALS}

Table 1 Profitability - Statistical paired t-test (Table no.1)

\begin{tabular}{|c|c|c|c|c|c|c|c|c|c|}
\hline Ratios & $\begin{array}{l}\text { Pre } \\
\text { Mean }\end{array}$ & $\begin{array}{l}\text { Post } \\
\text { Mean }\end{array}$ & $\begin{array}{l}\text { Pre } \\
\text { S.D }\end{array}$ & $\begin{array}{l}\text { Post } \\
\text { S.D }\end{array}$ & $\begin{array}{l}\text { Mean } \\
\text { (D) }\end{array}$ & $\begin{array}{l}\text { Standard } \\
\text { Deviation } \\
\text { (D) }\end{array}$ & $t_{c}$ & $\begin{array}{l}\text { Sig p-value } \\
\text { (2-tailed) }\end{array}$ & Result \\
\hline ROA & 21.08 & 12.18 & 2.51 & 1.18 & 8.89 & 5.692 & 3.495 & 0.025 & $\begin{array}{c}\mathrm{H}_{0} \\
\text { Rejected }\end{array}$ \\
\hline ROC & 20.59 & 18.48 & 6.01 & 1.44 & 2.10 & 14.824 & 0.318 & 0.766 & $\begin{array}{c}\mathrm{H}_{0} \\
\text { Accepted }\end{array}$ \\
\hline EBDITA & 40.34 & 36.34 & 7.93 & 7.72 & 4.06 & 9.668 & 0.940 & 0.400 & $\begin{array}{c}\mathrm{H}_{0} \\
\text { Accepted }\end{array}$ \\
\hline $\begin{array}{l}\text { Operating Profit } \\
\text { Margin }\end{array}$ & 36.90 & 32.75 & 8.40 & 8.45 & 4.14 & 10.404 & 0.891 & 0.423 & $\begin{array}{c}\mathrm{H}_{0} \\
\text { Accepted }\end{array}$ \\
\hline $\begin{array}{c}\text { Pre-tax Profit } \\
\text { Margin }\end{array}$ & 41.03 & 28.92 & 5.30 & 6.06 & 12.106 & 9.015 & 3.003 & 0.040 & $\begin{array}{c}\mathrm{H}_{0} \\
\text { Rejected }\end{array}$ \\
\hline $\begin{array}{l}\text { Net Profit } \\
\text { Margin }\end{array}$ & 38.16 & 20.51 & 5.17 & 4.33 & 17.054 & 8.786 & 4.340 & 0.012 & $\begin{array}{c}\mathrm{H}_{0} \\
\text { Rejected }\end{array}$ \\
\hline $\begin{array}{c}\text { Asset Turnover } \\
\text { Ratio }\end{array}$ & 0.54 & 0.59 & 0.08 & 0.07 & -0.05 & 0.059 & $\begin{array}{c}- \\
1.876 \\
\end{array}$ & 0.134 & $\begin{array}{c}\mathrm{H}_{0} \\
\text { Accepted }\end{array}$ \\
\hline $\begin{array}{c}\text { Receivables } \\
\text { Turnover }\end{array}$ & 3.95 & 0.566 & 0.67 & 1.43 & -1.71 & 1.96 & $\begin{array}{c}- \\
1.952 \\
\end{array}$ & 0.123 & $\begin{array}{c}\mathrm{H}_{0} \\
\text { Accepted }\end{array}$ \\
\hline
\end{tabular}


The statistical t-test applied on the data generated mixed results in terms of accepting and rejecting hypothesis. The statistical null hypotheses of ROA, Pre-tax Profit margin and Net income is rejected as there is decline in these ratios after merger. It means there is significant difference between these ratios before and after merger. The differences were statistically insignificant in these ratios Return on Capital, EBDITA and Operating Margin and hence those hypothesis were not rejected (accepted).

1. Return on Assets (ROA): It is quite evident from above table no. 1 that there is a significant difference in the mean value figures of the ratio i.e. 21.08 pre-merger $\&$ 12.18 post-merger with significant $p$-value less than the 0.05 so we have rejected the null hypothesis.

2. Pre-tax Profit margin: We have rejected the null hypothesis as the mean value figures of pre and post-merger, 41.03 and 28.92 with Mean Difference of 12.106 calculated in table no. 1 have significant value less than 0.05 . It means there is statistical significant difference between the pre and post-merger values.

3. Net Profit Margin: There is significant difference in the mean value figures of the ratio calculated above in the table no.1. The pre-merger mean is 38.16 and postmerger mean is 20.51 with Mean Difference 17.05 and significant $p$ value less than 0.05 . So, we have rejected the null hypothesis.

The observed decrease is highly significant $(\mathrm{p}=.025)$ of Return on assets, $(\mathrm{p}=.040)$ of pre tax profit margin and $(\mathrm{p}=.012)$ of net profit margin. Therefore, we can reject the null hypothesis that there is no difference in means and can assume with $99.9 \%$ confidence that the observed reduction in individual variables can also be found in throughout performance of firm after the merger. Apparently, the profitability and assets return are significantly changed after the merger. That difference is for short span of time once the other firm synergistic benefit is being consummated then there will be profitability surge in longer span of time. Putting assets on use will also improve over the time once things functioning are being regulated in the firm. Thus, gradual integration will surge the performance of firm and made it robust and healthier.

On the other hand, there was no statistical significant difference found in the mean figures of ROC, EBIDTA, Operating Profit margin, Asset turnover and Receivables Turnover ratios post-merger. There is less mean difference in these ratios with significant $p$-value greater than 0.05 so we have accepted the null hypothesis which states that there is no difference in pre and post-merger performance of firm.

\section{Hypothesis 2}

$\mathrm{H}_{0}$ : There is no significant change in liquidity and solvency of both companies post-merger.

$\mathrm{H}_{1}$ : There is significant change in liquidity and solvency of both companies post-merger. 
Impact of Cross-Border Acquisition on Financial Performance and Strategic Outcome of Acquiring Companies: Case Examples from Indian Pharmaceutical Industry

Table 2 Liquidity - Statistical paired t-test (Table no. 2)

\begin{tabular}{|c|c|c|c|c|c|c|c|c|c|}
\hline Ratios & $\begin{array}{l}\text { Pre } \\
\text { Mean }\end{array}$ & $\begin{array}{l}\text { Post } \\
\text { Mean }\end{array}$ & $\begin{array}{l}\text { Pre } \\
\text { S.D }\end{array}$ & $\begin{array}{l}\text { Post } \\
\text { S.D }\end{array}$ & $\begin{array}{l}\text { Mean } \\
\text { (D) }\end{array}$ & $\begin{array}{l}\text { Standard } \\
\text { Deviation }\end{array}$ & $t_{c}$ & $\begin{array}{l}\text { Sig p- } \\
\text { value(2- } \\
\text { tailed) }\end{array}$ & Result \\
\hline QR & 2.56 & 1.24 & 0.87 & 0.47 & 1.328 & 0.937 & 3.168 & 0.034 & $\begin{array}{l}\mathrm{H}_{0} \\
\text { Rejected }\end{array}$ \\
\hline $\mathrm{CR}$ & 5.71 & 2.61 & 1.62 & 0.96 & 3.094 & 1.419 & 4.889 & 0.008 & $\begin{array}{l}\mathrm{H}_{0} \\
\text { Rejected }\end{array}$ \\
\hline TD/E & 10.69 & 18.58 & 16.19 & 11.69 & -7.888 & 26.811 & $-\overline{0.658}$ & 0.547 & $\begin{array}{l}\mathrm{H}_{0} \\
\text { Accepted }\end{array}$ \\
\hline $\mathrm{TD} / \mathrm{C}$ & 8.34 & 14.97 & 11.24 & 8.82 & -6.686 & 19.511 & $\begin{array}{l} \\
0.766\end{array}$ & 0.486 & $\begin{array}{l}\mathrm{H}_{0} \\
\text { Accepted }\end{array}$ \\
\hline TD/TA & 7.47 & 11.94 & 10.26 & 6.97 & -4.472 & 16.769 & $-\overline{0.596}$ & 0.583 & $\begin{array}{l}\mathrm{H}_{0} \\
\text { Accepted }\end{array}$ \\
\hline
\end{tabular}

The statistical paired t-test applied on the data in table no. 2 indicates that there is significant difference in some ratios. The figures calculated in table no.2 shows decline in means of CR and QR ratios after merger with Mean Difference i.e. 1.328 and 3.094 respectively. The significant p-value of QR is 0.034 and $C R$ is 0.008 which is less than 0.05 . It means there is statistical significant difference between these ratios before and after merger. The differences were statistically insignificant in the other three ratios; Total Debt to Equity, Total Debt to Capital and Total Debt to Total Assets hence those hypotheses were not rejected (accepted).

The observed decrease in quick ratio and current ratio in pre and post mean are highly significant with p-value .034 and .008 than other solvency ratios. Hence, null hypothesis has been and rejected and accepted the alternative hypothesis which stated that there is difference in performance of firm after the merger. The decline in liquidity ratios may be due to absorption of liquidity of firm when firm buy another firm in hope of future synergistic benefits. Therefore, it represents declined liquidity after the merger is for short term but in long run positively hand out healthier liquidity. While on other hand, clearly showed increase in solvency ratios but insignificant related.

In the above tables 1 and 2 we have analysed the profitability and liquidity ratios of the Sun Pharmaceuticals by conducting the paired t-test on the financial ratios of the company. Clearly shows in both the tables that the liquidity and profitability of company is affected by merger.

Specifically, our result suggests that there is significant difference in the QR and CR after merger. These results suggest that there is significant difference in some of the profitability and liquidity ratios of the firm before and after merger. It indicates that firm do take time to absorbs other firm completely however, every firm has it's our positive and negative sides to get it absorbed by other firm. While integration of firm post-merger ought to be taken care off to give out better performance and profit in long run. Therefore, in short-run merger don't see that favourable but in long run those are really fruitful for survival and growth of the firm.

\subsubsection{BILCARE LTD}

\section{Hypothesis 1}

$\mathrm{H}_{0}$ : There is no significant change in profitability and operating efficiency of both companies post-merger.

$\mathrm{H}_{1}$ : There is significant change in profitability and operating efficiency of both companies post-merger. 
Table 3 Profitability - Statistical paired t-test (Table no. 3)

\begin{tabular}{|c|c|c|c|c|c|c|c|c|c|}
\hline Ratios & $\begin{array}{c}\text { Pre } \\
\text { Mean }\end{array}$ & $\begin{array}{c}\text { Post } \\
\text { Mean }\end{array}$ & $\begin{array}{c}\text { Pre } \\
\text { S.D }\end{array}$ & $\begin{array}{c}\text { Post } \\
\text { S.D }\end{array}$ & $\begin{array}{c}\text { Mean } \\
\text { (D) }\end{array}$ & $\begin{array}{c}\text { Standard } \\
\text { Deviation }\end{array}$ & $\mathrm{t}_{\mathrm{c}}$ & $\begin{array}{c}\text { Sig p- } \\
\text { value(2- } \\
\text { tailed) }\end{array}$ & Result \\
\hline ROA & 9.28 & 0.68 & 3.08 & 4.54 & 8.60 & 2.085 & 9.221 & 0.001 & $\begin{array}{c}\mathrm{H}_{0} \\
\text { Rejected }\end{array}$ \\
\hline ROC & 11.69 & 4.78 & 3.25 & 5.82 & 6.91 & 3.486 & 4.434 & 0.011 & $\begin{array}{c}\mathrm{H}_{0} \\
\text { Rejected }\end{array}$ \\
\hline EBIDTA & 24.72 & 19.82 & 1.30 & 17.68 & 4.29 & 18.58 & 0.517 & 0.632 & $\begin{array}{c}\mathrm{H}_{0} \\
\text { Accepted }\end{array}$ \\
\hline $\begin{array}{c}\text { Operating } \\
\text { Profit Margin }\end{array}$ & 21.03 & 6.40 & 1.67 & 4.21 & 4.62 & 2.887 & 11.324 & 0.000 & $\begin{array}{c}\mathrm{H}_{0} \\
\text { Rejected }\end{array}$ \\
\hline $\begin{array}{c}\text { Pre-tax Profit } \\
\text { Margin }\end{array}$ & 19.71 & 0.94 & 3.61 & 6.84 & 18.76 & 4.080 & 10.282 & 0.001 & $\begin{array}{c}\mathrm{H}_{0} \\
\text { Rejected }\end{array}$ \\
\hline $\begin{array}{c}\text { Net Profit } \\
\text { Margin }\end{array}$ & 13.32 & -0.08 & 2.28 & 5.80 & 13.40 & 3.631 & 8.257 & 0.001 & $\begin{array}{c}\mathrm{H}_{0} \\
\text { Rejected }\end{array}$ \\
\hline $\begin{array}{c}\text { Asset } \\
\text { Turnover } \\
\text { Ratio }\end{array}$ & 0.68 & 0.83 & 1.33 & 1.78 & -0.15 & 0.16 & -2.032 & 0.112 & $\begin{array}{c}\mathrm{H}_{0} \\
\text { Accepted }\end{array}$ \\
\hline $\begin{array}{c}\text { Receivables } \\
\text { Turnover }\end{array}$ & 4.15 & 3.30 & 0.68 & 0.45 & 0.85 & 0.38 & 4.958 & 0.008 & $\begin{array}{c}\mathrm{H}_{0} \\
\text { Rejected }\end{array}$ \\
\hline
\end{tabular}

The statistical t-test applied on the data shows that most of null hypothesis are rejected. The statistical null hypotheses of ROA, ROC Operating Profit Margin, Pre-tax Profit margin, Net income and Receivables Turnover are rejected as there is decline in means of these ratios after merger. It depicts that there is significant difference in these ratios before and after merger. The differences were statistically insignificant in the EBDITA, hence the hypothesis was not rejected (accepted).

1. Return on Assets (ROA): The calculated figures of this ratios in above table no. 3 depicts that there is a significant difference in the mean figures of the ratio i.e. 9.28 pre-merger \& 0.68 post-merger and Mead Difference of 8.60 with significant pvalue less than the 0.05 so we have rejected the null hypothesis.

2. Return on Capital: There is statistical significant difference in the calculated Mean figures of the ratio in table no.3, i.e., 11.69 per-merger and 4.78 post-merger with Mean Difference of 6.91. The significant p-value is also less than 0.05 so, we have rejected the null hypothesis.

3. Operating Profit margin: It is quite evident form the table no. 3 that mean figures of the ratio are significantly different. The pre-merger mean is 21.03 and postmerger mean is 6.40 with Mean Difference of 4.62 and significant p-value is also less than 0.05. So, we have rejected the null hypothesis.

4. Pre-tax Profit margin: We have rejected the null hypothesis as the mean figures of pre and post-merger are 19.71 and 0.94 respectively with Mean Difference of 18.76 calculated in table no.3. The significant value is also less than 0.05 . It means there is statistical significant difference between the pre and post-merger values.

5. Net Profit Margin: There is significant difference in the mean figures of the ratio calculated above in the table no.3. The pre-merger mean is 13.32 and post-merger mean is -0.08 with Mean Difference of 13.40. The significant p-value is also less than 0.05 . So, we have rejected the null hypothesis.

6. Receivables Turnover: We have rejected the null hypothesis as there is significant difference between the mean figures of the ratio in the above table no 3 . The premerger mean is 4.15 and post-merger mean is 3.30 with Mean Difference of 0.38 . 
Impact of Cross-Border Acquisition on Financial Performance and Strategic Outcome of Acquiring Companies: Case Examples from Indian Pharmaceutical Industry

The significant p-value is also less than 0.05 which means there is significant difference between the pre and post-merger values.

On the other hand, there was no statistical significant difference found in the mean figures of EBIDTA ratio post-merger. The significant $p$-value is greater than 0.05 so we have not rejected the null hypothesis (accepted).

As per our analysis of profitability ratio and operating efficiency ratio and t-test results the profitability and operating efficiency of the Bilcare ltd is affected by merger. Except assets turnover and EBITDA ratio, rest of the ratio of profitability and operating efficiency are significantly different in pre to post merger performance of firm. The declined changes in these ratios are highly significant since p-values are lesser than critical value. That significant decline is immediate performance of Bilcare after the merger which indicates that this apparent decline will transform into increase over the time as absorption of other entity takes time. Thus, operating efficiency and profitability of firm will increase over the time once energy of dispensing entity is accomplished in Bilcare.

\section{Hypothesis 2}

$\mathrm{H}_{0}$ : There is no significant change in liquidity and solvency of both companies post-merger.

$\mathrm{H}_{1}$ : There is significant change in liquidity and solvency of both companies post-merger.

Table 4 Liquidity - Statistical paired t-test (Table no. 4)

\begin{tabular}{|l|l|l|l|l|l|l|l|l|l|}
\hline Ratios & $\begin{array}{l}\text { Pre } \\
\text { Mean }\end{array}$ & $\begin{array}{l}\text { Post } \\
\text { Mean }\end{array}$ & $\begin{array}{l}\text { Pre } \\
\text { S.D }\end{array}$ & $\begin{array}{l}\text { Post } \\
\text { S.D }\end{array}$ & $\begin{array}{l}\text { Mean } \\
\text { (D) }\end{array}$ & $\begin{array}{l}\text { Standard } \\
\text { Deviation (D) }\end{array}$ & $\mathrm{t}_{\mathrm{c}}$ & $\begin{array}{l}\text { Sig p-value(2- } \\
\text { tailed) }\end{array}$ & Result \\
\hline $\mathrm{QR}$ & 2.49 & 0.18 & 1.98 & 0.07 & 2.316 & 1.959 & 2.642 & 0.050 & $\begin{array}{l}\mathrm{H}_{0} \\
\text { Accept }\end{array}$ \\
\hline $\mathrm{CR}$ & 6.69 & 2.42 & 1.78 & 0.28 & 4.242 & 1.566 & 6.055 & 0.004 & $\begin{array}{l}\mathrm{H}_{0} \\
\text { Rejected }\end{array}$ \\
\hline TD/E & 158.26 & 142.95 & 59.64 & 41.72 & 15.288 & 67.677 & 0.505 & 0.640 & $\begin{array}{l}\mathrm{H}_{0} \\
\text { Accepted }\end{array}$ \\
\hline TD/C & 59.43 & 57.87 & 10.10 & 7.09 & 1.562 & 11.009 & 0.317 & 0.760 & $\begin{array}{l}\mathrm{H}_{0} \\
\text { Accepted }\end{array}$ \\
\hline TD/TA & 52.83 & 44.87 & 9.48 & 7.35 & 7.954 & 11.375 & 1.564 & 0.193 & $\begin{array}{l}\mathrm{H}_{0} \\
\text { Accepted }\end{array}$ \\
\hline
\end{tabular}

The statistical paired t-test applied on the data in table no.4 indicates that there is significant difference in some ratios. The figures calculated in table no.4 shows decline in mean values of $\mathrm{CR}$ and $\mathrm{QR}$ ratios from 2.49 to 0.18 and from 6.69 to 2.42 after merger respectively. The mean differences of both these ratios are 2.316 and 4.242 respectively. The significant p-value of QR is 0.050 which is almost equal to the significant value so we accept the null hypothesis. The significant $p$-value of CR is 0.004 which is less than 0.05 . It means there is statistical significant difference in this ratio before and after merger. So, we have rejected the hypothesis. The differences were statistically insignificant in the other three ratios; Total Debt to Equity, Total Debt to Capital and Total Debt to Total Assets hence those hypotheses were not rejected (accepted). The liquidity ratios analysis and t-test results show that merger has very less effect on the liquidity of the company. Only current ratio within range of $p$-value 0.004 signifies change in pre and post-merger performance of firm. Thus, minimum effect has been found in liquidity and no effect on solvency of firm got changed post-merger.

Therefore, profitability and operating efficiency is majorly got changed after the merger of Bilcare ltd and minimum or no change in liquidity and solvency of Bilcare Ltd according to pvalue of significance level. There is limited immediate effect of merger of firm have showed. 


\section{CONCLUSION}

It is observed that there is immediate change in performance of pre to post merger of firm. That change could be positive or negative depending upon mainly on factors like identification of target, due diligence process before the merger, synergistic benefit and integration of firm after the firm. If there is any mismatch would lead to downward performance of firm after the merger of firm, if dispensing entity would not be consummated properly then there would be deterioration of firm in terms of decline in profit, liquidity and solvency of firm. It is being so evident in both cases that prompt performance after the merger is unstable and unclear but gives results over the years.

\subsection{Financial Outcome}

The merger and acquisition outcome has definitely effected both the companies which is quite evident form our analysis conducted in table $1,2,3 \& 4$. The hypothesis 1 , that was, there is no significant difference between the profitability and operating performance of companies before and after merger can't be fully accepted or rejected. The overall profit of Sun Pharma is negatively affected. This suggests that there was greater increase in assets compared to its net income because the operating efficiency has not changed and overall revenue is not effected but the profits show a decline after merger. Similarly, in Bilcare Ltd the analysis shows that there is decline in profitability of company post-merger and operating efficiency is also effected due to decline in receivables turn over. The second hypothesis, was that there is no significant difference between the liquidity and solvency of the companies before and after the merger. The analysis of this hypothesis depicts that merger has no impact on the long term solvency of the company but definitely affects the liquidity of both the companies. There was decline in the liquidity ratios of Sun Pharmaceuticals Ltd. and Bilcare Ltd. post-merger. These findings in Indian context are sync with the Saboo and Gopi (2009); Vishwanathan and Neethu (2015); Menapara and Pithadia; and Gupta and Banerjee (2017).

\subsection{Strategic Outcome}

Merger and Acquisitions being inorganic growth strategy requires a long process for being implemented. The effective and efficient due diligence process is the prerequisite for the success of the transactions. Though every company goes under the process of due diligence before the transactions takes place, still in many cases, the results are not in the favour of the companies after the deal is completed. The Sun Pharmaceutical's acquisition of Dusa is successful as the strategy was to enter into a new market with new product at less cost. Dusa had good market share in USA and proven technical capabilities with USFDA approved manufacturing. This helped the Sun Pharma to enter into dermatological treatment devices with good growth opportunities. According to the report of credit Susie, there is one digit decline in the Sun Pharmaceuticals profitability in year 2018. The report further stated that the subsidiaries of Sun Pharma like Dusa, URL, and Ranbaxy etc. are performing well at their end in their markets, so, the decline in profits is due to the problem in the Sun Pharmaceuticals itself. So, according to this report we can say that the strategy to acquire the Dusa was successful but the decline in profitability of Sun Pharmaceuticals lies with the company itself. There are motives behind for every inorganic growth strategy as the Bilcare acquired the Global Flims Business of the INEOS because they found that combining efforts and capabilities could provide a strong strategic fit for both the companies. But as per our analysis and results the overall desired results are not achieved as there is decline in profitability and operating efficiency is also affected postmerger.

The study indicates that the financial outcome and strategic outcome are directly related to each other. It is evident from our analysis that mergers and acquisitions do effect the financial 
Impact of Cross-Border Acquisition on Financial Performance and Strategic Outcome of

Acquiring Companies: Case Examples from Indian Pharmaceutical Industry

performance of acquiring companies as there is increase in assets which effects the operating performance which indirectly affects the liquidity and solvency of company. The strategic fit between the companies which are going to merge is very important for the success of companies' performance.

\subsection{Limitations}

The study is mainly based on the secondary data which is derived from the annual financial reports of the companies. So, the reliability and findings are completely dependent and contingent upon the published data in these reports. The study period is limited to only five years before and after merger. Accounting or financial ratios used have their own limitations, which are applied to the study. The sample size is small so the generalization of results for the industry application cannot be applied here.

\section{Abbreviations:}

S.D

Mean (D)

Standard Deviation (D)

$\mathrm{t}_{\mathrm{c}}$
Standard Deviation

Mean Difference

Standard Deviation Difference

Calculated $\mathrm{t}$

\section{REFERENCES}

[1] Andrade, G, "New Evidence and Perspectives on Mergers" Journal of Economic Perspectives - Volume 15, Number 2-Spring 2001—Pages 103-120

[2] Aggarwal, A. and Jaffe, J. F, "The Post-merger Performance Puzzle" Applied Economics Letters 3, 2000, Page No, 221-223.

[3] Bahunia, A., "Financial Performance of Indian Pharmanceutical Industry- A Case Study" Asian Journal of Management Research, ISSN 2229-3795.

[4] Bertrand, O. and Bestchinger, M. A, Performance of domestic and cross-border acquisitions: empirical evidence from Russian acquirers, 2011

[5] Bertrand, O. and Zitouna, H, Domestic versus cross-border acquisitions: which impact on the target firms' performance?, 2008

[6] Beena, P.L, "An analysis of mergers in the private corporate sector in India." CDS working papers, no.301. Trivandrum: CDS, 2000

[7] Bilcare Chairman's Statement on its acquisition of Global Flims Business: http://www.business-standard.com/article/companies/q-a-mohan-bhandarichairman-and-md-bilcare-110080900011_1.html. Accessed as on 28 March, 2018.

[8] Credit Suisse Report on Sun Pharmaceuticals Ltd. Performance, by Krishna R., on 4 september, 2107 https://www.bloombergquint.com/markets/2017/09/04/creditsuisse-sees-tough-times-ahead-for-sun-pharma. Accessed as on $28 \mathrm{March}, 2018$.

[9] Dutta, S. and Jog, V, “The Long-Term Performance of Acquiring Firms A Re-Examination of an Anomaly." Journal of Banking \& Finance, 33, 2009, pp 1400-1412.

[10] Gupta, B., and Banerjee, P, "Impact of Merger and Acquisition on Financial Performance of Companies: Evidence from Selected companies in India. IMS Business School, ISBN 978-93-85895-57-9, 2017

[11] Kerkel et al, Short Strategich Human resource development. 1967, Page No 40.

[12] Neethu, T. C., and Vishwanathan, A study on Financial Performance of companies before and after Merger and Acquisition. Indian Journal of Research. Volume 4, Issue 3, 2015, ISSN 2250-1991. 
[13] Moeller, F. and Schlingemann, R. Stulz, "Firm size and the gains from acquisitions", Journal of Financial Economics, 73, 2004, pp 201-228.

[14] Martynova, L. Renneboog, "A century of corporate takeovers: what have we learned and where do we stand?", Journal of Banking and Finance, 32, 2008, pp 2148-2177.

[15] Meena, S, "Prospects of Global Mergers and Acquisitions - An Indian Overview", International Journal of Research in Business Management (IMPACT: IJRBM) ISSN (E): 2321-886X; ISSN (P): 2347-4572 Vol. 2, Issue 9, Sep 2014, 71-80.

[16] Menapara, M. and Pithadia, V., "A Study on Financial Performance of Selected Companies during Pre-Post Merger and Acquisition. Abhinav Journal, Volume No.1, Issue No. 11 ISSN 2277-1166.

[17] Mishra, P, "R\&D Efforts by Indian Pharmaceutical Firms in the New Patent Regime", South East European Journal of Economics and Business, Vol. 5, No. 1, 2010, pp. 83-94

[18] Mishra, P, "Determinants of Inter-Industry Variations in Mergers and Acquisitions: Empirical Evidence from Indian Manufacturing Sector", Artha Vijnana, Vol. 53, No.1, 2011, pp. 1-22

[19] Prakash, S, "The Impact of Mergers and Acquisitions on Shareholders' Value: An Empirical Analysis of Select Indian Companies" Indian Journal of Finance 2017, Vol. 11 Issue 9, 2017

[20] Saboo, S., and Gopi, S, "Comparison of Post-Merger Performance of Acquiring Firms (India) involved in Domestic and Cross-Border Acquisitions", MPRA Working Paper No. 19274, 2009

[21] Sophia, S. \& Jacunda, Maria Evelyn, . "Do Acquisitions Add Value to Acquirers in India? A Study on the Sensitivity of the Stock Market and Acquirer Returns" "Indian Journal of Finance 2017, Vol. 8 Issue 5, 2014

[22] Sun Pharmaceutical Ltd Press Release of Acquisition as on December 2012: https://www.sunpharma.com/node/11112. Accessed as on 28 February, 2018.

[23] Sun Pharmaceuticals Stock market report Report, by Somvanshi on June 1, 2017: https://economictimes.indiatimes.com/markets/stocks/news/what-went-wrong-forsun-pharma-a-tragedy-in-4-parts/articleshow/58937650.cms

[24] Vyas, V., Narayanan, K., and Ramanthan, A., "Determinants of Mergers and Acquisitions in Indian Pharmaceutical Industry" Eurasian Journal of Business and Economics 2012, 5 (9), 79-102. 